\title{
An analysis of the declining support for the ANC during the 2011 South African local government elections
}

\author{
C TWALA
}

\begin{abstract}
Local government elections are notorious for low voter turnout, but the May 2011 elections in South Africa showed a record 58 percent of the 24 million registered voters. In South Africa, local government matters and not just because it provides a pointer to what might happen in the provincial and national elections due in 2014, but helps in determining the readiness of the African Nation Congress in providing basic services to the different communities. Interestingly, these elections were preceded by service delivery protests against the ANC. The article is an analysis of the decreased support for the ANC during the 2011 local government elections. The multifaceted reasons behind the boiling cauldron of this decline in support for the ANC are scrutinised. Underpinning this decline in support often lie deep and complex factors which can be uncovered through a careful analysis of the ANC's campaigning strategies ahead of these elections; the media which has been accused of rampant sensationalism; service delivery protests and mudslinging from other political parties. However, it is not the author's intention in this article to deal with how other parties fared during these elections, but to highlight their impact on the declined support received by the ANC in the elections. The discussion is presented in four parts: the first presents an exploratory discussion on the theory of local government in the sphere of governance. The second part discusses some key strategies and tactics used by the ANC in attempts to galvanise support, as well as the challenges encountered. The third deals with the opposition parties' machinery in preventing the ANC from getting a majority vote during the election. Lastly, the article concludes by highlighting the lessons learnt by the ANC during these elections within the framework of electoral politics in South Africa.
\end{abstract}

Keywords: local election 2011, African National Cxongress (ANC), local government.

Disciplines: History, political science, electoral studies.

\section{Introduction}

The narrative about the ANC's decline, which had gained much traction among certain sections of the media which painted the party as venally corrupt, wholly inefficient and lacking the political will to chart a different path, did not resonate with the majority of ANC members, nor with the party's key constituencies among the rural and urban poor. Despite

1. History Department, University of the Free State, South Africa. 
this, the elections were preceded by a series of unprecedented events. With the service delivery protests experienced prior to the elections, the ANC faced a stiff challenge from the Democratic Alliance (DA) as the official opposition.

According to Tsheola (2012: 163), the Department of Cooperative Governance and Traditional Affairs attributes the failure of local government service delivery to "political parties that undermine the integrity and functioning of municipal councils through intra- and inter-party conflicts and inappropriate interference in councils and administration". In order to weaken the ANC, in the main, other political parties aimed at extracting support from its base. The ANC's patchy performance in government also risked greater voter apathy and a withdrawal from politics among the marginalised, as many communities did not bother to vote in the face of service delivery deficits.

The 2011 local government elections again upended most of the contrary speculation that had preceded it. Pertinent questions asked in this article about these elections are: How does a political party such as the ANC that presides over one of the most unequal societies in the world, where one in three workers is jobless, and nearly half the citizens live in poverty manage to triumph despite a decline in support? Why, in the face of dozens of community service delivery protests attesting to widespread disgruntlement at the government's performance and the indifferent conduct of many local politicians and officials, would the electorate continue voting for a party that they claim has failed to deliver services? Is it true that the decline in support for the ANC was engineered by its members, particularly those who felt disgruntled about some of the councillors' conduct? Attesting to the above, Gwede Mantashe, General Secretary of the ANC stated:

\section{You find that in the majority of cases a march is led by members of the $A N C$. The $A N C$ carried out its own study of recent protests, so it probably has good evidence for this statement. Moreover, our own investigations tend to confirm its validity (Alexander, 2010: 34).}

The article attempts to analyse the reasons for the decline of the ANC's support after the May 2011 local government elections. In doing so, a surge of violent service delivery protests in poor constituencies against inept council performance will be scrutinised as one of the contributing factors; another is the collapse of 20 ANC Councils in the North West province; and governance paralysis in the Eastern Cape province resulting from bitter infighting between elements of the ANC and its allies. Furthermore, the study investigates a contested argument on the role played by opposition parties in their attempts to make inroads into the ANC's support. Here I refer to the decline in the proportional share of the entire pool of registered voters. This does not indicate a decline in the absolute number of votes cast in favour of the ANC.

\section{Theoretical framework underpinning municipal governance in South Africa}

The policy of separate development in apartheid South Africa was entrenched by the establishment of local government legislation in which categories of municipalities were designated as black or white local authorities. The Group Areas Act 41 of 1950 (later amended to Act 36 of 1996) made provision for blacks/non-whites (i.e. Africans, Coloureds, and Indians) to live separately, with Africans being confined to the 'native reserves'. Furthermore, one of the main reasons for the establishment of the three Bantustans of

TD, 8(2), December 2012, pp. 200-216. 
Transkei, Bophuthatswana and Venda in 1976 and 1977 was to spread propaganda about providing homelands for Africans (Adams, et al., 1999).

However, despite the above, the democratisation of South Africa which began during the early 1990s with the release of political prisoners and the unbanning of liberation movements, led to a negotiated settlement regarding several issues pertaining to local government (Netswera \& Phago, 2011: 131). The issues included: enforcing the new demarcation of municipalities; the training of local government officials; and the provision of new local government Acts for the effective administration of the different municipalities which were initially seen as apartheid structures.

Prior to the May 2011 local government elections, the South African Institute of Race Relations (SAIRR) in its 2010 annual survey provided an overview of municipality byelection results since South Africa's last nation-wide local government elections in 2006. During that period the ANC won 17 municipal by-elections but lost 55, meaning that it suffered a net loss of 38 wards. Over the same period the DA lost 5 municipal by-elections but won 29, meaning that it made a net gain of 24 seats (SAIRR, South Africa Survey 2009/2010: Politics and Government). Even allowing for the DA's caution about which byelections it contested, its superior winning record was self-evidently an auspicious sign of its chances of improving on its 2006 performance when it won $14.9 \%$ of the votes cast, against the ANC's ability to amass $66.3 \%$ or just under two-thirds of the vote. The net position of the ANC and the DA after their losses and gains was that the ANC controlled 306 local government seats against the 61 held by the DA. Therefore, the ANC controlled five times as many municipal councils as the DA (Louw, 2011a).

The above summary paints a picture of a steady decline in support as experienced by the ANC as early as 2006. An analysis shows that although this decline occurred on a small scale during the by-elections, there were dire long-term consequences for the ANC in future local government elections. Such consequences also became evident during the 2011 local government elections in South Africa. This situation is endorsed by Kimmie (2012: 115-131) who indicates that a low voter turnout was the result of poor candidate screenings. Furthermore, ANC community participation faltered in many instances due to candidate rivalry, the application of gender, youth and race quotas and, in particular, the imposition by higher ANC structures of candidates who would aid strategic positioning for Mangaung 2012 .

\section{The ANC's strategies and tactics ahead of the elections}

In order to gain support and avoid the envisaged decline in its support base during the May 2011 local government elections, the ANC embarked on using some of the below mentioned strategies and tactics. It is argued in this section that some of these purported strategies and tactics contributed to the ANC's declining support ahead of, and during the voting period.

\section{The ANC's slogan of a 'better life for all'}

In order to understand the ANC's strategies and tactics ahead of the May 2011 local government elections, it is important to highlight the fact that its manifesto essentially reiterated and reaffirmed the existing promises made during past elections, rather than providing an innovatory programme of action pertinent to the problems of municipal 
misgovernment in South Africa. The party even repeated the promise of creating a 'better life for all South Africans', though more than 16 years had lapsed since that slogan was first used in its election campaign for the watershed 1994 elections (Louw, 2011: 5). It is interesting to note that this slogan appealed to other voters, but the decline in the electorate persisted, despite the organisation's manifesto which was said to be relevant to both the local and national government elections.

\section{The use of Nelson Mandela's legacy}

During the May 2011 local government elections, the ANC was tempted to deploy identity politics. For example, in the run-up to these elections, it raised the very sensitive issue of the ownership of national symbols and liberation songs. In the meantime, the legacy of former President Nelson Mandela was exploited by both the ANC and the DA. To justify the above, the Secretary General of the ANC, Gwede Mantashe argued in the Justice Malala e-TV programme called The Justice Factor that the leaders of the DA, such as Helen Zille, should refrain from employing opportunistic tactics by using Mandela's legacy to project an image of the DA. He accused the DA as a party which, in its attempts to galvanise support, purported to adhere to Mandela's ideals. He went on to suggest that Zille should confine herself to using the names and legacies of Helen Suzman and Colin Eglin, former leaders of the Democratic Party (forerunner of the DA). This suggestion by Mantashe raised the serious danger of identity politics. Ironically, Suzman as a politician in her own right played a significant role in challenging the apartheid government when long-term political prisoners were inhumanely treated in prisons. Furthermore, she played a critical role in ensuring the access of all political prisoners, who were eligible, to distance learning and academic development. Therefore, the quality of her political contribution should not be limited only to opposition party politics.

Mamphela Ramphela, former Vice Chancellor of the University of Cape Town (UCT) argued that Mantashe's statement echoed those of a few ANC members who publicly expressed concerns that the ANC leadership was allowing Zille to use Mandela as an icon. According to Ramphela, Mandela was not just the President of the ANC, but also of South Africa. Moreover, Mandela, the icon, belonged to all South Africans as the ffather of the nation'. He worked tirelessly to project himself as reaching out to those who opposed the political settlement he championed. It is clear from Ramphela's statement that Mandela could not be appropriated by any sector of South Africa's population (Sunday Times, 29 May 2011: 5). It may be argued that the ANC should be more generous in acknowledging the contributions of both ANC and non-ANC members to the struggle for freedom in South Africa.

The above was, in one way or another, an indication that the ANC was trapped in a situation of using its past struggle credentials to gain support. It is argued in this article that there was nothing wrong with the ANC's using its past struggle credentials in positioning itself amongst the electorate, but that the party should, at the same time, re-position itself as a political party of the future. The attempts used by the ANC to solely 'monopolise' the legacy of Mandela for its gain during the May 2011 local elections elicited more criticisms from non-ANC members, as was the case with Ramphela.

TD, 8(2), December 2012, pp. 200-216. 


\section{The cleansing of the Solomon Mahlangu statue}

During the run-up to the local government elections, there were some activities which showed how intolerant the political parties could be. As a strategy and an attempt to discredit the DA, the ANC also took the extraordinary step of commissioning a cleansing ceremony of the Solomon Mahlangu statue in Tshwane (Mamelodi) on 5 May 2011, after the DA had held a Freedom Day rally there ahead of the local government elections. The ANC in the city enlisted the services of sangomas (Traditional healers) to cleanse the statue (Sowetan, 9 May 2011: 3). This was another attempt by the ANC to focus on personalising politics and it was unclear as to why the ANC felt so threatened by the hegemony of its own ideas and legacy, when these were embraced by the DA during the election campaign. Perhaps this could have been that some in the ANC recognised the possibility of other political parties succeeding in appropriating its space of their struggle heritage.

\section{A 'tea girl' humiliation saga}

The former President of the African National Congress Youth League (ANCYL), Julius Malema spurned the opportunity to debate political issues with Lindiwe Mazibuko, the former DA spokesperson ahead of the local government elections when he stated:

\section{She's a nobody; she's a tea girl of the madam. I'm not debating with the service of the madam'}

Although Malema became more popular with such utterances, this had negative consequences for the ANC's electorate because the so-called 'tea girls' also constitute ANC voters. It was unjustifiable of Malema to equate Mazibuko with a 'tea girl'; thus showing how insensitive he was to other electorates. The ANC was aware that the profiling of Mazibuko by the DA in its electioneering team attempted to penetrate the mass of black voters, particularly the same section of the population such as the 'tea girls' who were devalued and humiliated by Malema's utterances. According to Maserumule and Mathekga (2011: 11821197), featuring Mazibuko in its electioneering team was the DA's political strategy to placate black voters and shrug off the perception that it is a white party.

\section{Some contributing factors to the decline of the ANC's support}

\section{Dealing with the DA's machinery}

It is interesting to note that the election manifestoes of both the ANC and the DA were, in essence, not all that different from each other. As could be expected, they were for the most part vague, non-committal and full of generalisations. The buzz word for the May 2011 local government elections was 'service delivery' to communities. The essence of the promise was that in future, voters who had not experienced adequate services by both the ANC and the DA in their respective provinces would have these services provided.

An increase in the number of votes by the DA in the May 2011 local government elections in one way or another suggests that the party is gradually becoming acceptable to African voters. Owing to a service delivery backlog under the ANC government in many of the African townships during the run-up to the elections, it was common to hear people saying: 


\section{I will vote $D A$ locally for delivery in my municipality and ANC nationally for its} history in my country (Business Day, 20 May 2011: 1).

Without doubt, such statements are an indication that a change of leadership at municipal level is necessary. Although it is clear that the DA made some inroads into the ANC's support base which could have contributed to its decline in support, the latter quickly dispelled these arguments and stated that the former's growth was being exaggerated by the media. It is argued in this article that while the votes received by the DA in the townships were not enough to change the ANC's control, they are an indication of a significant shift in the country's voting patterns. For example, in an upset, the DA won ward 32 in Johannesburg from the ANC which included Buccleuch and part of Alexandra, an ANC stronghold (Business Day, 20 May 2011: 1).

In the Eastern Cape, the DA increased its number of councillors in the Nelson Mandela Bay Metro, where the ANC scraped through with 51 percent of the vote. This translates into the ANC's having 61 seats out of 120 in the metro. This means that if only one ANC councillor is absent from a council meeting, the party will not be able to pass by-laws without opposition support. A key result for the DA was also its retention of control of the Midvaal Council in Gauteng with an increased majority, after the ANC threw almost everything into winning back the municipality (Daily Maverick, 19 May 2011: 1).

In dealing with the DA's electioneering campaign, the ANC criticised its principal poster which featured photos of three women; namely, Helen Zille in the centre, Patricia De Lille to her right, and Lindiwe Mazibuko, a black DA MP to her left. This photo allegedly presented the message that the party was for all colours. To the ANC's annoyance, Zille also took the fight right into its (ANC's) territory, interspersing her English and Afrikaans with isiXhosa. According to Southern and Southall, Zille annoyed the ANC leadership when she sang reworked 'struggle songs' and danced toyi-toyi, leading to Malema saying that she was dancing like a monkey. Even more annoying to the ANC was her claim that, while the ANC had become increasingly racialised, the DA had become the party of non-racialism, embodying the vision and values of Mandela (Southern \& Southall, 2011: 78). By doing so, the DA wanted to occupy the traditional political space of the ANC and legitimise its relevance to the black populace.

\section{The Malema Factor and the 'White thieves' remarks}

After the announcement of the election results, it was not surprising that the ANC's support had declined in many of the country's provinces. The ANC managed to get 62 per cent, a drop of 4 percent from 66 percent in the 2006 elections. In giving an explanation as to why there was a decline in the votes, Mantashe said certain remarks by Malema had been detrimental to the party. For example, Malema had made a comment at a rally in the Northern Cape Province about 'white thieves' (Sunday Independent, 29 May 2011: 16). In this rally, Malema stated that the whites in South Africa were not to be reimbursed for the purchase of land which he argued was 'stole' from the black people. Ironically, although Zuma and other senior members of the ANC were present at the rally, not a single leader of the party or Zuma as the President, reprimanded Malema. Therefore, the remarks made by Malema in front of the senior leaders of the ANC could have been interpreted as an endorsement by the party; something that Mantashe regarded as having been detrimental to the ANC electorate.

TD, 8(2), December 2012, pp. 200-216. 
The issue of whether Malema cost or benefited the ANC was not new and appeared rather complex. It was also not clear as to why Mantashe waited until after the election results to tell the nation of their disapproval of Malema's comments. Zuma, who took the platform after Malema, did not rebuke Malema or state that such remarks were not part of the ANC's collective thinking and traditions. Possibly, ANC supporters expected the leaders of the party to take corrective measures in time, in order to minimise the damage that such statements could have caused. Although Mantashe distanced the ANC from Malema's statement that white people should be treated as 'criminals' for 'stealing' land from black people, the damage had already been done (Business Day, 25 May 2011: 3). The above stigmatisation of legitimate dissent as 'racist' became a routine response of the Zuma administration during the elections under discussion and was not free of this contagion. Zuma denounced criticism of the government and the ANC in the media as 'unpatriotic' (Business Day, 21 June 2011).

Mantashe was correct in echoing the statement that the Malema factor had alienated minority groups. Yet in the same vein, I opine that the Malema factor attracted many young voters, particularly those at tertiary level, to the ANC. One needs to examine Malema's poise and charm, and the warmth with which he was received whenever he visited such campuses to address students. It should be noted that during the 1994 election campaign, Winnie Mandela and Peter Mokaba were very discreetly withdrawn from the campaign due to the racial statements they had uttered (Barnard, 1994: 121). However, it was not the case this time with Malema; his inflammatory speeches and actions might have motivated the youth, but they had a very negative effect on the image of the party that Zuma wished to project.

\section{Undermining the Coloured voters prior to the elections}

Besides the above remarks by Malema, another senior member of the ANC and chief government spokesperson Jimmy Manyi declared that there was an overconcentration of Coloureds in the Western Cape and that they should be spread over the entire interior of the country if they were to access government basic services. This was however, interpreted as one way of undermining the Coloured voters who reside in the Western Cape. Subsequently, he was rebuked by another ANC heavyweight, Trevor Manuel and referred to as a 'racist'. This mudslinging from senior ANC members had, to a certain extent, a negative impact on the Coloured voters in the Western Cape who might have wanted to vote for the party. The ANC's mayoral candidate Tony Ehrenreich conceded that Manyi's comments exposed the ANC to criticism that it was a racist party (Business Day, 20 May 2011: 1).

In the Western Cape Province the ANC failed to convince the Coloured communities to vote for it. The DA's victory in the area can be explained in different ways; namely, that the ANC had failed to deal with the growing gap between the political interests of black and Coloured working-class communities, and a stronger convergence between the political interests of affluent and poor areas. The candidacy of Tony Ehrenreich who was a workingclass hero proved to be a blunt weapon against the above-mentioned dynamics (Dikeni, 2011: 1199-1209).

\section{Exploiting the 'White Rich' and 'Black Poor' scenario}

Within the emerging discourse of governance in South Africa's provinces, the fact that the Western Cape is the only province which is not under the jurisdiction of the ANC posed some serious challenges for the ruling party. For propaganda purposes, the ANC tried to classify Cape Town into the 'White Rich' and the 'Black Poor' categories. During its 
electioneering period, the ANC argued that the DA's provincial government perpetrated the imbalances which existed between the 'White Rich' and the 'Poor Black'. Some of the national and provincial leaders of the ANC implied in their speeches that the 'Poor Blacks' live in health-hazard places because the taxes that they pay are used to benefit the whites in the province. By so doing, the ANC implanted a notion of entitlement by telling its members that the Cape Town City Council under the DA's administration owed them houses, free water and free electricity (Cape Argus, 25 May 2011: 16). In the main, these utterances by the ANC's leaders and the deployment of senior party members to canvass support in the Western Cape did not yield any positive results, as the DA became victorious in most municipalities in the province. It was clear that dividing people in terms of social stratification of 'rich' and 'poor' failed to appeal to most voters in the Western Cape where the DA dominated.

\section{The impact of the late commencement of campaigning by the ANC}

The ANC started campaigning for these elections at a very late stage. The late entry in the electioneering race had an impact on the election results of the party. However, it should be noted that the campaign intensified two months before the elections. The party should have rejoiced in gaining 62 per cent of the votes during the elections, because the stakes were high in terms of the strategies and tactics employed during the electioneering period. Part of the 4 per cent the ANC lost, can possibly be traced to several party activists who registered as independents in protest against unpopular candidates who were forced on communities.

One other party which capitalised on the shortcomings of the ANC in governance was the Congress of the People (COPE). This party which started as a force to be reckoned with during the 2009 national elections when it won enough votes to form opposition coalitions in municipalities, also cost the ANC (Twala, 2010; Maserumule \& Mathekga, 2011). Booysen (2012: 311) states that voters who had become unhappy with the ANC largely abstained in 2011, rather than switching to an opposition party. This indicated that there was a slight decline in support for the ANC that could not be attributed to the strong campaigning strategies of opposition parties. Despite these shortcomings, immediate qualitative and quantitative research show that the ANC's performance was, in fact, in line with international trends of electorates gradually abandoning self-assured ruling parties. However, for the ANC, a party that has won every election since the dawn of democracy in 1994, the results were unacceptable. The ANC, being the oldest liberation movement in Africa, could not afford to flaunt its struggle credentials and expect that the party's rich history to be a permanent magnet to draw voters.

Giving an analysis of the above, Abbey Makoe, the founder and editor-in-chief of Royal Services wrote the following:

Even at its peak the ANC, while led by the phenomenally popular Nelson Mandela,
Walter Sisulu, Govan Mbeki, former Rivonia Trialists and Robben Islanders and
prominent returned exiles, the ANC could not muster a 100 percent election victory.
This was in spite of the vast majority of South Africans, including all the minority
groups, hailing Mandela and the ANC's humane policy of reconciliation in a country
scarred by decades of racial strife. Now, if Mandela himself, the man virtually regarded
as our living political saint, could not succeed in rallying the entire electorate, why
would the lesser mortals in today's ANC believe they could secure every voter's faith?
(Daily News, 26 May 2011: 18).

TD, 8(2), December 2012, pp. 200-216. 


\section{Strategies and tactics employed by the ANC}

As mentioned previously, the ANC began its electioneering campaign hardly 2 months before the elections. In his address at the launch of the manifesto, at the Royal Bafokeng Stadium in Rustenburg in the North West Province, Zuma admitted, in what might legitimately be described as a calculated understatement, that there were some municipalities that were "not performing well", as manifested by the rising number of service delivery protests (Louw, 2011c).

In many of the wards which were contested, all the political parties put up posters bearing the faces and names of their local candidates. Some of the candidates on the posters, including those of the ANC, were not known to the voters or the constituencies. Except for being paraded during the election rallies, in most cases these candidates failed to vigorously embark on campaigns that helped the ANC to win the previous elections, such as door-to-door campaigns. Instead the electorate received pamphlets stuffed in their postboxes with prattle about the services provided by the ruling party.

In February 2011, in a rally held in Mthatha in the Eastern Cape, Zuma told an audience that an ANC membership card provided an automatic pass to heaven and that

when Jesus fetches us, He will find wearing black, green, and gold being the only ones belonging to the $A N C$.

During this rally, Zuma defined members of the ANC as the chosen people who were assured of a place in heaven when they die, unlike those who supported the opposition parties. He stated:

When you are carrying an $A N C$ membership card you are blessed. When you get there, different cards are used, but if you have an ANC card you will be let through (Louw, 2011b).

He further added that those who desert the ANC would mean that

the ancestors of this land... Hintsa, Ngqika and Shaka will all turn their backs on you (Hamill \& Hoffman, 2011: 57).

Zuma also said that the

ANC will rule until Jesus comes again (City Press, 10 April 2011: 4).

In saying the above, Zuma was not straying too far from the theme of ANC members enjoying preferential treatment from God, as ancestor worship is an important element in the religious beliefs of many African people. It was not the first time that Zuma had presented the ANC as the movement that is favoured by God. In the run-up to the 2009 national and provincial elections, Zuma asserted that the ANC would rule until 'Jesus comes again', a clear manifestation of the 'divine right' mindset. The implication of this declaration was that only Jesus could replace the ANC, and this, in turn, invested the ANC with a special status (Louw, 2011b).

However, it was not clear as to whether Zuma's inclination to trespass into the field of religious eschatology was merely an attempt to exploit the intellectual vulnerabilities of the less educated people or whether he genuinely believed that the ANC had the blessing of God in their exercise of political power; notwithstanding the vulnerability of many of its leaders to the temptations of corruption. The religious leaders described these statements by Zuma as 
'blasphemous' and a serious transgression; that of Zuma's depiction of heaven as a sanctuary for people dressed in the colours of the ANC.

Reacting to Zuma's remarks from a political rather than from a religious perspective, Zille said:

\section{If Zuma has been quoted correctly, his words combine blasphemy, intimidation and blackmail. It is unbelievable that the president of a constitutional democracy can threaten voters with such untruths (Louw, 2011b).}

The ANC, however, dismissed the whole saga over Zuma's remarks, describing them as 'figurative' and 'metaphorical' expressions which should not have been taken literally. It likened them to everyday expression such as 'a marriage made in heaven' and 'a heavenly voice' (Louw, 2011b). However, the above expressions were innocuous compared with Zuma's presentation of the ANC as an elected body which is guaranteed a place in heaven. Simply, people's membership of a political party which is stained with corruption and contaminated with greed, being promised a place in the heavenly realms, defies explanation.

The manner in which ANC had run its election campaigns revealed the gaps that continued to exist between the commitment to implement the strategy and the political desire to win over voters, through public relations and politicking. Cunningly, the party did not send Zuma to hotspot areas such as Ficksburg ${ }^{2}$, Balfour, Ermelo and Zandspruit where its candidates were randomly chosen (Tsheola, 2012: 174; Booysen, 2011: 151-152). This, despite the presentation of Zuma as an accessible, down-to-earth and listening president compared to his predecessors.

During the campaigning period, it was also noticeable that government ministers, premiers and MECs used rallies to galvanise people to vote for the ANC. The message spread by these politicians was that voters should change the councillors and other local government officials who were not providing quality service to them. Therefore, they had to vote for the ANC as the party with the power to deal with such problems. Ironically, in most cases the service delivery protests happened in the areas governed by the ANC. In South Africa the provision of services to communities is viewed as the prerogative of the local sphere of government (Hemson et al., 2009; McLennan, 2009; Gumede, 2009; Andrews \& Shah, 2005). Therefore, it is not surprising to find that most of the rallies were turned into music festivals and places where food parcels were distributed to communities in need. It may be argued that this was done in order to divert communities' attention from failing service delivery projects.

As happened during the 2009 national elections, in KwaZulu-Natal (KZN), Zuma's home province, the ANC, to a certain extent successfully used the royal family to gain votes in the so-called IFP strongholds (Twala, 2010: 66-83). This was the same strategy used by the IFP for many years when garnering votes in the province. On 22 February 2011, KZN Premier,

2 Perhaps the most memorable event of the pre-2011 local government polls was the killing by the police of Andries Tatane from Ficksburg during the service protest march in the area on 13 April 2011. Unable to subdue Tatane by their severe blows to his naked upper torso, the police resorted to shooting him. It was widely reported and shown in the media that rubber bullets were pumped into his chest at close-range killing him instantly. He was killed while residents of Ficksburg were registering their discontent over the pace and quality of municipal services. Ficksburg was not peculiar in that regard. Protests had erupted throughout the country, in what had become a common feature on the eve of local polling.

TD, 8(2), December 2012, pp. 200-216. 
Zweli Mkhize, in the State of the Province Address, announced projects and finances around the royal family (State of the Province Address, 22 February 2011).

Although the above-mentioned strategies and tactics helped the ANC win votes, there was to a degree, some negative implications. For example, when Zuma told a small farming community in the North West Province that they would have to explain themselves to their ancestors should they not vote for the ANC, he did not expect a fierce backlash to his threat. Five days later, for the first time since 1994, the ANC lost ward 6 in Vrischgewacht, one of its long-time strongholds in Tswaing, to the DA. Residents said they were fed-up with the ANC's empty promises, its arrogant leadership and lack of service delivery. What made the defeat even more bitter for the ANC was that the DA did not campaign in the area and had not fielded a candidate for councillor until two weeks before local elections (Sunday Independent, 29 May 2011: 8).

When the ANC leadership in the region put up a candidate not popularly elected by the community, David Malo, a member of the party at the time, approached the DA and promised to win them the ward. This heralded a two-week door-to-door campaign which won the DA the ward and highlighted the ANC's election list process which the party had promised to investigate and deal with cases of manipulation. With the ANC in the doldrums and refusing to grant the community its preferred leaders despite protests, the DA staged a coup (Sunday Independent, 29 May 2011: 8). Zille's officials parachuted into the area, among them Kathleen Oosthuizen and Nicky Vos, two women respectively known as 'Mapule' and 'Palesa' to capitalise on the fallout between the community and the ANC, and the former's discontent with poor service delivery in the area (Sunday Independent, 29 May 2011: 8).

The above strategies and tactics of the ANC were, in one way or another, successful in winning votes. Opportunistically, the ANC evoked Nelson Mandela, Oliver Tambo, Hector Pieterson and Chris Hani to emotionalise the election. At the ANC Siyanqoba Rally at the FNB Stadium in Johannesburg, a large portion of Zuma's speech was about the past legacy of the ANC. It was also at this rally that the DA was dubbed a dangerous organisation and insinuations were made that it was trying to take the country back to apartheid. Zuma spoke of the brutality of the apartheid system and the attempt in 1976 to impose Afrikaans on black people. He called on ANC members to "forgive but never forget" (Sowetan, 19 May 2011: 11). Conveniently, the ANC presented its successes since 1994.

It was during the Siyanqoba Rally that Zuma outlined the party's strategy known as the Local Government Turnaround Strategy to redress the problems experienced by the municipalities. According to the plan, among other things, the ANC planned to build systems to accelerate quality service delivery in municipalities; deal with corruption and maladministration; ensure that councillors were more accountable to communities; professionalise municipalities through employing qualified and experienced personnel; improve national and provincial policy, support and oversight to local government; and strengthen partnerships between local government, communities and civil society (Sowetan, 19 May 2011: 11).

\section{Complaints about the election lists}

A political analyst, Ndletyana, argued that it was during these elections that the ANC found itself vulnerable because the threat was not only posed by the DA or the service delivery protests, but also stemmed from within. Members protested against regional and provincial leadership over the nomination of candidates. They charged that the leadership flouted the rules, overlooking individuals who had been nominated by members at the branches, and 
were endorsed by their communities (Ndletyana, 2011: 1117-1119). In order to allay the fears and any imminent revolts by voters, particularly those from the ANC, a week before the elections Zuma announced that his party would order an investigation into irregular candidate nominations and remove candidates who had irregularly been placed on the party's election lists. This was an oversight by the ANC because it came at a late stage with the verification of the candidates' lists.

After the elections the ANC appointed a team to investigate irregularities in the compilation of the party's lists of candidates. Announcing the names of the seven-member investigative team led by Minister of Home Affairs Nkosazana Dlamini-Zuma, Mantashe said their work would not be influenced by the cries of those who purported to be members of the ANC, but reacted against it. He stated:

\section{W're not going to work on the basis of who protested. The team will take its time, do a thorough job, and make good recommendations based on the information collected and not on voices that are very loud and disruptive of the work" (The Times, 25 May 2011: 4).}

However, Mantashe further committed the ANC to rooting out members placed irregularly on the candidates' lists.

\section{The toilet saga}

It is interesting to note that the campaign was enlivened by two new stories, which revealed much about political discourse and practice in South Africa. The DA, which controls the city of Cape Town and is the main rival of the ANC at national level, campaigned on a platform of efficient and effective service delivery, including the provision of waterborne sewerage in low income housing areas. Subsequently, in December 2009, the DA was taken to court by the ANCYL for failing to construct the superstructure, namely, the four walls and a roof above 1316 toilets that had been installed in Makhaza, part of Khayelitsha Township in Cape Town (SAIRR, South Africa Survey 2009/2010: Politics and Government; Tempelhoff, 2012: 82-102). ${ }^{3}$

The Western Cape High Court ruled that the city council was violating the residents' constitutional right to dignity and its own duty to provide for the basic needs of the poor

The background to this toilet saga is as follows: In 2004, the Cape Town Municipality decided to upgrade the informal settlement at Silvertown in Khayelitsha in terms of the Housing Act's Upgrading of the Informal Settlement Programme (UISP). As part of this project, one communal toilet was to be provided for every five households (the 1:5 ratio). In July 2007, the community expressed unhappiness with communal toilets and demanded that an individual toilet be provided for each household. The municipality held a meeting with the community in late November, at which it was agreed that, in addition to the communal toilets that were already in use, each of the erven would be provided with an individual toilet. However, the community would have to enclose the individual toilets themselves, as the municipality would be providing 1316 unenclosed toilets. A tender for the individual toilets was issued in 2009 and completed by the end of that year. These toilets were enclosed by the residents themselves, except in Makhaza. At this point the ANCYL approached the South African Human Rights Commission (SAHRC), filing a complaint that it was a violation of human dignity that the residents of Makhaza had to use these unenclosed toilets and cover themselves with blankets in full view of the public.

TD, 8(2), December 2012, pp. 200-216. 
(Ntliziywana \& De Visser, 2001: 3-4). The story was splashed all over the media by the ANC, only for an identical example to be unearthed in a poorly performing ANC-run municipality, Moqhaka in the Free State, where 1620 toilets built as far back as 2003 had never been enclosed. The media reported that the contractor responsible for building these toilets was the husband of the mayor of the town of Viljoenskroon in the Moqhaka Municipality and who happened to be an ANC member. Suddenly the issue was no longer just about inadequate service delivery, but was also one of nepotism. It threatened to undercut the ruling party's message of being a caring government, illuminating an already existing pathology of the self-indulgent political elite who perceived political office as an opportunity to 'eat', rather than to provide a public service (Ndletyana, 2011: 1117-1119). The pictures of unused toilets situated in the middle of residential plots appealed to the media, but the issue was also emblematic of wider problems in the local government elections.

The above mudslinging by the ANC and the DA over the toilet saga highlighted that for these two political parties, their election campaigns were more about berating each other for the failings of which they were equally guilty, than of making new commitments to improving the lives of the electorate. It may be argued that the ANC knew about the 'toilet saga' in its own Free State municipality, Moqhaka, but kept quiet about it.

\section{A perspective on future local government elections and lessons learnt}

The results of the May 2011 general elections were fascinating. Although there was a decline in the ANC's support, the elections reflected a consistent partisan loyalty phenomenon. The majority of voters had not yet deviated from the post-apartheid voting patterns wherein voting was facilitated along racial lines. Overall, power did not actually change hands, and the country at present is still dominated by two major parties namely, the ANC and the DA, with just a weak voice from the other 120 smaller parties. Nationally, the ANC performed steadily, obtaining 62 percent, with the DA showing an impressive improvement of 24 percent. Although there was a decline in support for the ANC, smaller parties as in the past, failed to take advantage of this by attracting ANC dissenters. This served as a lesson to these smaller parties that fragmentation of the opposition comes perilously close to decimating them. Their dwindling support had, unfortunately, boosted the two behemoths as voters lost confidence in the smaller parties thereby boosting the two main contenders. This was also the case with the breakaway parties, mostly formed during electoral seasons by disgruntled members of the older, more established parties. Breakaways usually make a small but significant showing at their beginnings, and subsequently trudge on thereafter. This is evident from the performance of the United Democratic Movement (UDM) in 2000; the Independent Democrats (ID) in 2006; and COPE in 2009. As a new party during the May 2011 local government elections, the National Freedom Party (NFP) which broke away from the Inkatha Freedom Party (IFP) also did not perform as expected (Sithole, 2011).

These elections also had serious implications for ANC President, Jacob Zuma, because under his stewardship, the ruling party had steadily lost support in both the 2009 national election and in the May 2011 local government elections (Business Day, 23 May 2011: 2). Furthermore, it is interesting to note that disgruntled ANC supporters stayed away, rather than switching their voting allegiance. The challenge for the ANC in May 2011 was thus not major losses to the opposition, but a low turnout from its constituencies. The ANC attempted to arrest the situation by amending its candidate selection process for this election, 
so as to facilitate greater public and community participation; a move intended to encourage alienated supporters back into the voting booths (Brown, 2011: 3). Tim Cohen commented in Business Day that the election results for the ANC as a ruling party showed a "glass half full, half empty" characteristic. The ANC had won convincingly, but nevertheless, had lost some support. The party lost ground in all provinces except in KZN compared to the previous local government elections, and declined everywhere compared to the general election (Business Day, 23 May 2011: 10).

Justin Sylvester, a political researcher at the Political Information and Monitoring Service Programme at IDASA wrote in the Cape Times that the promises made by the ANC politicians in exchange for votes had also involved threats that delivery on some socioeconomic rights, as provided for in the constitution, would not happen unless community members 'voted correctly'. A perception was created by the ANC that the assistance and the rights that citizens have to social grants, for example, must be rewarded with electoral support (Cape Times, 17 May 2011: 9). Any such impression was a cruel distortion of the social contract in a rights-based constitutional state such as South Africa. Allowing or creating such an impression in the minds of voters entirely undermines the fundamental political rights of citizens and further disproportionately marginalises the poor.

\section{Conclusions}

Without doubt, the fierce challenge launched by the DA on the ANC during the May 2011 local government elections sent a clear message to the ruling party to keep its house in order. With this contest, the ANC is expected to make a clean break with the qualitative decline of the last decade of its century. It must bridge the gap between its electoral successes and the capacity to lead society. In order to continue being a majority party in South Africa, the ANC should emerge with an agenda to re-engineer its moral content, leadership, intellectual and strategic capacity and internal political consciousness in a manner that seeks to reverse the current conditions of its internal decline.

The cause of the ANC's decreased support at the polls is not hard to fathom. The plurality of voices throughout the entire ANC family, which often resulted in conflicting messages and public spats between prominent leaders of the tripartite alliance, were the first symptoms of the battle for space in the highest echelons of the party. There is nothing wrong with vociferous internal discourse in accordance with the party's constitution; however, when that spills out into the open, the sympathetic voter can only feel confused, bewildered and disappointed, as well as disaffected.

In analysing the 2011 elections, it is clear that the community service delivery protest did not automatically imply condemnation of the ideals and even of the leaders of the ANC; rather, it may be seen as an appeal for intervention to uphold those values and ideals and call to order individuals and structures seen to be damaging the party and its history. Paradoxically, a protest could also be a backhanded vote of confidence in the ANC, as long as the party is prepared to address grievances and act to resolve them. Although the ANC won the elections, it is evident that there was a shift away from the predominantly African party towards the traditionally white but in fact, non-racial opposition. Therefore, it is clear from the above analysis that the May 2011 elections disputed the widely held view that the ANC is a permanent magnet attracting voters in South Africa.

TD, 8(2), December 2012, pp. 200-216. 


\section{References}

Adams, M., Cousins, B. \& Manana, S. (1999) Land tenure and economic development in South Africa. London: Overseas Development Institute.

Alexander, P. (2010) Rebellion of the poor: South Africa's service delivery protests - a preliminary analysis, Review of African Political Economy, 37, 123, p. 34.

Andrews, M. \& Shah, A. (2005) Assessing local government performance in developing countries, in: Shah, A. (ed.) Public sector governance and accountability series: Public service delivery. Washington D.C.: The International Bank for Reconstruction and Development), 63-80.

Barnard, S.L. (1994) The election campaign of the general election in South Africa in 1994, Journal for Contemporary History, 19, 2, p. 121.

Booysen, S. (2011) The African National Congress and the Regeneration of political power. (Johannesburg: Wits University Press), pp. 151-152.

Booysen, S. (2012) Regeneration of ANC political power, from the 1994 electoral victory to the 2012 centenary, in: Lissoni, A, et al. One hundred years of the ANC: Debating liberation histories today. (Johannesburg: Wits University Press), p. 311.

Brown, K. (2011) Local elections: Same as before, only more so, Southern Africa Report, 29, 11, 16 March, p. 3.

Business Day, 20 May 2011; 23 May 2011; 21 June 2011.

Cape Argus, 25 May 2011.

Cape Times, 17 May 2011.

City Press, 10 April 2011.

Daily Maverick, 19 May 2011.

Daily News, 26 May 2011.

Dikeni, L. (2011) Western Cape local government elections: triumph of the political over racial and religious identities?, Journal of Public Administration, 46, 3/1, pp. 11991209.

Gumede, W.M. (2009) Delivering the Democratic Developmental State in South Africa, in: McLennan, A. \& Munslow, B. (eds.) The politics of service delivery. (Johannesburg: Wits University Press), pp. 43-98.

Hamill, J. \& Hoffman, J. (2011) The African National Congress and the Zanufication debate, in: J. Daniel (ed.) New South Africa Review 2: New paths, old compromises? (Johannesburg: Wits University Press), p. 57.

Hemson, D. et al. (2009) Service delivery as a measure of change: State capacity and development, in: Kagwanja, P. \& Kondlo, K. (eds.) State of the Nation: South Africa 2008. (Cape Town: Human Sciences Research Council Press), pp. 151-177.

Kimmie, Z. (2012) The performance of the African National Congress in the 2011 Local Government Elections, in: Booysen S, (ed.), Local Elections in South Africa: People, Parties, Politics. (Johannesburg and Stellenbosch: Sun Press), pp. 115-131. 
KwaZulu-Natal State of the Nation Address. (2011) KwaZulu-Natal Working together to take South Africa forward. Pietermaritzburg, p. 4.

Louw, R. (ed.) (2011a) Survey shows Democratic Alliance poised to make gains against ANC in local government elections this year, Southern Africa Report, 29, 5, pp. 1-2.

Louw, R. (ed.) (2011b) Concern over Zuma's ANC gateway to heaven, Southern Africa Report, 29, 6, pp. 4-5.

Louw, R. (ed.) (2011c) ANC reiterates its promises in local election manifesto, Southern Africa Report, 29, 9, p. 6.

Maserumule, M.H. \& Mathekga, M. (2011) A glimpse into the future of the Congress of the People, Journal of Public Administration, 46, 3/1, pp. 1182-1197.

McLennan, A. (2009) The delivery paradox, in: McLennan, A. \& Munslow, B. (eds.) The politics of service delivery. (Johannesburg: Wits University Press), pp. 19-42.

Ndletyana, M. (2011) Contextual perspective: 2011 Local Government Elections - Turning of the tide?, Journal of Public Administration, 46, 3/1, pp. 1117-1119.

Netswera, G. \& Phago, K.G. (2011) Perceptions about Municipal Governance in the post1996 era: The case of Thulamela Local Municipality, Africa Insight, 41, 2, p. 131.

Ntliziywana, P. \& De Visser, J. (2011) Assessing the risks of Zuma's call for 'fresh elections' after 18 May, in: The South African Local Government briefing. Rondebosch: SA Local Government Research Centre), pp. 3-4.

Sithole, J. (2011) Inkatha Freedom Party - National Freedom Party dynamics in the KwaZulu-Natal Province, Journal of Public Administration, 46, 3/1, pp. 1169-1181.

South African Institute for Race Relations (SAIRR). (2009/2010) Politics and Government, Pretoria, pp. 11; 33-34.

Southern, N. \& Southall, R. (2011) Dancing like a monkey: The Democratic Alliance and opposition politics in South Africa, in J. Daniel (ed.), New South Africa Review 2: New paths, old compromises? (Johannesburg: Wits University Press), p. 78.

Sowetan, 9 May 2011.

Sowetan, 19 May 2011.

Sunday Independent, 29 May 2011.

Sunday Times, 29 May 2011.

Tempelhoff, J.W.N. (2012) From Makhaza to Rammulotsi: Reflections on South Africa's "toilet election" of 2011, Historia, 57, 1, May, pp. 82-102.

The Times, 25 May 2011.

Tsheola, J.P. (2012) Theorising a democratic developmental state: Issues of public service delivery planning and violent protests in South Africa, Journal of Public Administration, 47, 1, March, pp. 163-173.

Twala, C. (2010) Jacob Zuma's 'Zuluness' appeal during the April 2009 elections in South Africa: An attempt to break the IFP's grip on Zulu social and political structures?, Journal for Contemporary History, 35, 2, pp. 66-83.

TD, 8(2), December 2012, pp. 200-216. 
Twala, C. (2010) The Congress of the People (COPE): A new political dynamic during the April 2009 campaign and election?, Journal for Contemporary History, 35, 3, pp. 89111. 